ЕКСПЕРИМЕНТАЛЬНО-ТЕОРЕТИЧНИЙ РОЗДІЛ

DOI 10.35220/2078-8916-2020-36-2-2-9

УДК: 616.311-07-089.22-089.27:612.014.421.8:611-018

О. В. Павленко, д. мед. н., *I. М. Савицька, к. мед. н., М. А. Бойко

Національна медична академія післядипломної освіти імені П. Л. Шупика, Київ

*ДУ «Національний інститут хірургії

та трансплантології імені О. О Шалімова» НАМН України, Київ

\section{МОРФОЛОГІЧНА ХАРАКТЕРИСТИКА РАНЕВОГО ПРОЦЕСУ СЛИЗОВОЇ ОБОЛОНКИ ПОРОЖНИНИ РОТА В ЗАЛЕЖНОСТІ ВІД СПОСОБУ 3'ЄДНАННЯ КРАЇВ РАНИ}

Мета дослідження. Порівняти та проаналізуват перебіг процесів регенерації слизової оболонки порожнини рота після з'єднання країв рани за допомогою шовного матеріалу на основі шовку та п-бутил-2иіаноакрилатної клейової композиції в експерименті. Матеріал і методи. Дослідження було проведено у відділі експериментальної хірургії Національного інституту хірургії та трансплантології ім. О.О. Шалімова НАМН Украӥни на 24 безпородних статевозрілих кролях-самиях, віком 16-18 місяиів, масою тіла від 2260 до 3425 гр (середня вага $2843 \pm 100$ гр) у зв'язку зі схожістю гістологічної будови слизової оболонки з людською. Тварини були поділені на контрольну та основну групи по 12 тварин у кожній. Під внутрішньовенним наркозом 3 мл $5 \%$ розчину тіопенталу натрію та 6 мл 1 \% розчину пропофолу та місиевою інфільтраиійною анестезією $2 \%$ розчином лідокайну (0,5 мл), за допомогою леза скальпеля №15 наносили різану повздовжню рану розміром 1,5-2,0 см в довжину та 0,3-0,5 см в глибину на слизову оболонку верхньої щелепи по перехідній складиі присінку порожнини рота. В контрольній групі тваринам було проведено з'єднання країв рани слизової оболонки порожнини рота шляхом накладання вузлуватих швів на основі шовку з покриттям (USP (EP): 5/0(2), 0,75м, piжуча голка, «OPUSMED»). В основній групі кожній $з$ тварин проводили з'єднання країв рани слизової оболонки порожнини рота за допомогою п-бутил-2иіаноакрилатної клейової композичії «Histoacryl».

На 3, 7 та 14 добу тварин виводили з експерименту передозуванням 5\% розчину тіопенталу натрію. Зразки тканин в зоні втручання для гістологічного дослідження видаляли так, щзоб в їх межі потрапив рановий канал з відступом по 3 мм в обидві сторони від рани.

Результати. В основній групі тварин, спостерігалось пришвидшення репаративних проиесів у рані за рахунок швидкої деструкиії клейових мас, надійного з'єднання країв рани, меншій травмі тканин починаючи з 3 доби. Запальна відповідь, мала пік на 3 добу, інтенсивність якої стрімко спадала до 7 доби. На 14 добу, спостерігалось рівномірне сполучнотканинне утворення, яке місиями візуально не відрізнялось від інтактних ділянок СОПР. В контрольній групі, після використання шовного матеріалу на основі шовку, спостерігалась виражена запальна реакиія на 3 добу, яка зберігалась до 14 доби. Пік запалення, в контрольній групі припадав на 7 добу. На 14 добу ознаки запалення дещуо зменшувались, але були присутні за рахунок «стороннього тіла» у рані, рубець мав ознаки деформації та підвищувався над рівнем інтактних ділянок слизової оболонки.

Висновки. Застосування клейової композиції сприяло швидшому відновленню тканин в зоні хірургічного втручання, про щзо свідчать ознаки регенерації, які спостерігались з 3 доби, а саме, поява молодих колагенових волокон та тонкого прошарку молодої грану-

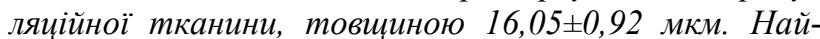
більш оптимальне загоєння рани в основній групі, відбувалось на 7 добу після хірургічного втручання, $i$ проявлялось прискоренням формування ніжного нормотрофічного сполучнотканинного рубия, про щзо свідчить ивидиа зміна клітин лімфоцитарномакрофагального ряду та часткове відновлення епітеліальної пластинки. Вже на 14 добу ділянка втручання не відрізнялась від навколишніх інтактних ділянок. Перевагою використання клейової композиції в порівнянні із шовним матеріалом, починаючи з 7 доби, є відсутність в післяопераційній рані «стороннього тіла», швидкість та легкість застосування.

Ключові слова: слизова оболонка порожнини рота, шовний матеріал, n-бутил-2-цііаноакрилатна клейова композиція, з'єднання тканин, хірургія порожнини poma.

\section{А. В. Павленко, *И. М. Савицкая, Н. А. Бойко}

Национальная медицинская академия последипломного образования имени П. Л. Шупика, Киев

*ГУ «Национальный институт хирургии и трансплантологии имени А. А. Шалимова» АМН Украины, Киев

\section{МОРФОЛОГИЧЕСКАЯ ХАРАКТЕРИСТИКА РАНЕВОГО ПРОЦЕССА СЛИЗИСТОЙ ОБОЛОЧКИ ПОЛОСТИ РТА В ЗАВИСИМОСТИ ОТ СПОСОБА СОЕДИНЕНИЯ КРАЕВ РАНЫ}

Цель исследования. Сравнить и проанализировать ход процессов регенерачии слизистой оболочки полости рта после соединения краев раны с помощью шовного материала на основе шелка $u$ n-бутил-2цианоакрилатной клеевой композиции в эксперименте. Материал и методы. Исследование было проведено в отделе экспериментальной хирургии Национального института хирургии и трансплантологии им. A. А. Шалимова НАМН Украины на 24 беспородных половозрельх кроликах-самиах в возрасте 16-18 месяцев, массой тела от 2260 до 3425 гр (средний вес $2843 \pm$ 100 гр) в связи со сходством гистологического 
строения слизистой оболочки с человеческой. Животные были разделены на контрольную и основную группь по 12 животных в каждой. Под внутривеннымм наркозом 3 мл 5 \% раствора тиопентала натрия и 6 мл $1 \%$ раствора пропофола и местной инфильтрачионной анестезией $2 \%$ раствором лидокаина $(0,5$ мл), с помощьюю лезвия скальпеля №15 наносили резаную продольную рану размером 1,5-2,0 см в длину $и$ 0,3-0,5 см в глубину на слизистую оболочку верхней челюсти по переходной складке преддверия полости рта. В контрольной группе животным было проведено соединения краев раны слизистой оболочки полости рта, путем наложения узловатых швов на основе шелка с покрытием (USP (EP): 5/0 (2), 0,75, режущая игла, "OPUSMED»). В основной группе каждому из животных проводили соединения краев рань слизистой оболочки полости рта с помощью п-бутил-2цианоакрилатной клеевой композиции «Histoacryl».

На 3, 7 и 14 сутки животных выводили из эксперимента передозировкой 5 \% раствора тиопентала натрия. Образиь тканей в зоне вмешательства для гистологического исследования удаляли так, чтобы в их предель попал раневой канал с отступлением по 3 мм в обе стороны от раны.

Результаты исследований и их обсуждение. $B$ основной группе животных, наблюдалось ускорение репаративных прочессов в ране за счет быстрой деструкиии клеевых масс, надежного соединения краев рань, меньшей травме тканей начиная с 3 суток. Воспалительный ответ, имел пик на 3 сутки, интенсивность которой стремительно падала до 7 суток. На 14 сутки, наблюдалось равномерное соединительнотканное образование, местами визуально не отличалось от интактных участков СОПР. В контрольной группе, после использования шовного материала на основе шелка, наблюдалась выраженная воспалительная реакция на 3 сутки, которая сохранялась до 14 суток. Пик воспаления в контрольной группе приходился на 7 сутки. На 14 сутки признаки воспаления несколько уменьшались, но присутствовали за счет «инородного тела» в ране, рубеи имел признаки деформации и возвышался над уровнем интактных участков слизистой оболочки.

Выводы. Применение клеевой композиции способствовало быстрому восстановлению тканей в зоне хирургического вмешательства, о чем свидетельствуют признаки регенерации, которые наблюдались с 3 суток, а именно, появление молодых коллагеновых волокон и тонкой прослойки молодой грануляиионной ткани, толщиной 16,05 \pm 0,92 мкм. Наиболее оптимальное заживление раны в основной группе, происходило на 7 сутки после хирургического вмешательства, и проявлялось ускорением формирования нежного нормотрофического соединительнотканного рубиа, о чем свидетельствует быстрое изменение клеток лимфоцитарного-макрофагального ряда и частичное восстановление эпителиальной пластинки. Уже на 14 сутки участок вмешательства не отличался от окружаюших интактных участков. Преимуществвом использования клеевой композиции по сравнению с шовным материалом, начиная с 7 суток, является отсутствие в послеоперачионной ране «инородного тела».

Ключевые слова: слизистая оболочка полости рта, шовный материал, п-бутил-2-цианоакрилатна клеевая композиция, соединение тканей, хирургия полости pma.

\section{O. V. Pavlenko, *I. V. Savitskaya, M. A. Boiko}

P.L. Shupik national medical Academy of postgraduate education, Kiev

*State Institution “A. A. Shalimov National Institute of Surgery and Transplantology", Academy of Medical Sciences of Ukraine, Kiev

\section{MORPHOLOGICAL CHARACTERISTICS OF THE WOUND PROCESS OF THE ORAL MUCOSA, DEPENDING ON THE METHOD OF CONNECTING THE EDGES OF THE WOUND}

Purpose of the study. Compare and analyze the course of the processes of regeneration of the oral mucosa after joining the edges of the wound using suture material based on silk and n-butyl-2-cyanoacrylate adhesive composition in the experiment.

Material and methods. The study was conducted in the department of experimental surgery of the National Institute of Surgery and Transplantology. A. A. Shalimova of the National Academy of Medical Sciences of Ukraine on 24 outbred sexually mature male rabbits aged 16-18 months, body weight from 2260 to $3425 \mathrm{~g}$ (average weight $2843 \pm 100 \mathrm{~g}$ ) due to the similarity of the histological structure of the mucous membrane with the human one. Animals were divided into control and main groups of 12 animals each. Under intravenous anesthesia $3 \mathrm{ml}$ of a $5 \%$ solution of sodium thiopental and $6 \mathrm{ml}$ of a $1 \%$ solution of propofol and local infiltration anesthesia with a $2 \%$ solution of lidocaine $(0.5 \mathrm{ml})$, using a scalpel blade No. 15, a cut longitudinal wound of 1.5-2.0 cm size was applied in length and 0.3-0.5 cm in depth on the mucous membrane of the upper jaw along the transitional fold of the vestibule of the oral cavity. In the control group, the animals were joined by the edges of the wound of the oral mucosa by applying knotted sutures based on coated silk (USP (EP): 5/0 (2), 0.75, cutting needle, “OPUSMED”). In the main group, each of the animals was joined by the edges of the wound of the oral mucosa using the n-butyl2-cyanoacrylate adhesive composition "Histoacryl".

On days 3, 7 and 14, the animals were removed from the experiment by an overdose of 5\% sodium thiopental solution. Tissue samples in the intervention area for histological examination were removed so that the wound channel with a deviation of $3 \mathrm{~mm}$ to both sides of the wound fell within their limits. Selected tissue samples were fixed in a $10 \%$ solution of neutral formalin for 24 hours, dehydrated in ethanol with increasing concentrations (from 70 to 100 $\circ \mathrm{C})$, enlightened in xylene for 30 minutes, kept for 2 hours at $37^{\circ} \mathrm{C}$ in a mixture of xylene and paraffin (1: 1), and twice in paraffin for 30 min at $56^{\circ} \mathrm{C}$, compacted in paraffin, made histological sections $5 \mu \mathrm{m}$ thick, which were stained with hematoxylin and eosin, picrofuxin according to van Gieson. 
Photo documentation of histological preparations was carried out using a Leica ICC50 HD digital optical microscope camera and morphometric processing using a video analyzer and the Paradise computer program developed by the "Eva» research and production company.

Research results and discussion. In the main group of animals, acceleration of reparative processes in the wound was observed due to the rapid destruction of the adhesive masses, reliable connection of the edges of the wound, less tissue injury starting from 3 days. The inflammatory response had a peak at 3 days, the intensity of which rapidly dropped to 7 days. On the 14th day, a uniform connective tissue formation was observed, in places it did not visually differ from the intact sections of the oral mucosa. In the control group, after the use of suture material based on silk, a pronounced inflammatory reaction was observed on day 3, which lasted up to 14 days. The peak of inflammation in the control group was on the 7 th day. On day 14, signs of inflammation decreased slightly, but were present due to a "foreign body" in the wound, the scar had signs of deformation and rose above the level of intact sections of the mucous membrane.

Conclusions. The use of the adhesive composition contributed to the rapid tissue repair in the surgical area, as evidenced by the signs of regeneration that were observed from 3 days, namely, the appearance of young collagen fibers and a thin layer of young granulation tissue, 16.05 $\pm 0.92 \mu \mathrm{m}$ thick. The most optimal wound healing in the main group occurred on the 7th day after surgery, and was manifested by the acceleration of the formation of a gentle normotrophic connective tissue scar, as evidenced by the rapid change in the cells of the lymphocyticmacrophage series and partial restoration of the epithelial plate. Already on the 14th day, the intervention site did not differ from the surrounding intact sites. The advantage of using the adhesive composition compared to suture material, starting from 7 days, is the absence of a "foreign body" in the postoperative wound.

Key words: oral mucosa, suture material, n-butyl-2cyanoacrylate adhesive composition, tissue connection, oral surgery.

Bcmyn. Будь-які хірургічні втручання на м'яких тканинах передбачають створення рани, що потребує обов'язкового з'єднання ii країв для забезпечення якнайшвидшого загоєння та профілактики ранніх післяопераційних ускладнень $[1,2]$. Відомо, що характер та вид рубця залежить від процесів, які відбуваються в рані на ранньому післяопераційному періоді, на які впливає вид 3'єднання країв рани $[1,2]$.

Проблема вибору методу з'єднання країв рани завжди була актуальною темою для дискусій [1-5]. Незалежно від методу, основні цілі з'єднання тканин залишаються однаковими. Сюди відноситься мінімізація ризику приєднання ранової інфекції, належне зближення та співставлення країв рани для досягнення прийнятного естетичного та функціонального результату $[5,6]$. Тому якісне з'єднання слизової оболонки в хіру- ргії порожнини рота є фінальним етапом і запорукою успішного лікування пацієнтів, адже від обраного методу, ретельності виконання та часових витрат буде залежати успіх всього втручання [7].

Наразі, накладання швів, вважається методом вибору для наближення та з'єднання країв рани [8], однак присутній ряд недоліків при застосуванні даного методу [5,9]. Тому існує потреба в пошуку альтернативних варіантів, одним 3 яких $є$ тканинні клейові композиції. Досвід хірургів різних спеціальностей вказує, що ціаноакрилатні клейові композиції нового покоління менш токсичні, міцні на розрив, швидко полімеризуються, мають бактеріостатичні властивості та високу біосумісність, виявляють гемостатичні властивості та прості у використанні $[4,8,9]$. Проте відсутні дані в науковій літературі про динаміку морфологічних змін при загоєнні ран слизової оболонки порожнини рота, з'єднаних n-2бутил-ціаноакрилатною клейовою композицією.

Mema. Порівняти та проаналізувати перебіг процесів регенерації слизової оболонки порожнини рота (СОПР) після з'єднання країв рани за допомогою шовного матеріалу на основі шовку та n-бутил-2-ціаноакрилатної клейової композиції в експерименті.

Матеріали та методи дослідження. Експериментальні дослідження були проведені у відділі експериментальної хірургії Національного інституту хірургії та трансплантології ім. О. О. Шалімова НАМН України на безпородних статевозрілих кролях-самцях, віком 16-18 місяців, масою тіла від 2260 до 3425 гр (середня вага $2843 \pm 100$ гр) у зв'язку зі схожістю гістологічної будови слизової оболонки 3 людською [10,11]. Усі тварини пройшли ветеринарний огляд та мали груповий паспорт здоров'я 3 необхідними профілактичними заходами. Шляхи придбання, умови утримання, методи знеболювання відповідали Правилам виконання робіт з використанням експериментальних тварин, затвердженим МO3 України. Усі роботи з тваринами були виконані 3 дотриманням заходів етичного та гуманного поводження відповідно до положень Конвенції Ради Європи з біомедицини та законів України, а також погодженні 3 Комітетом медичної етики Національної медичної академії післядипломної освіти імені П. Л. Шупика. Також під час експерименту керувалися Законом України № 3447-IV «Про захист тварин від жорстокого поводження» (2006), стандартами Guide for the core and Use of Laboratory Animals (National Academy Press, Revised, 1996) та American Heart Association's "Guidelines for the Use of Animal in Reseach" [12]. Втручання виконувалися в стерильних умовах під загальною та місцевою анестезіями [13]. 
Тварини були поділені на контрольну, та основну групи, по 12 тварин у кожній. В контрольній групі, кожній з тварин було проведено з'єднання країв рани СОПР шляхом накладання вузлуватих швів на основі шовку. В основній групі тваринам було проведено з'єднання країв рани СОПР за допомогою n-бутил-2-ціаноакрилатної клейової композиції.

Наркоз досягався внутрішньовенним введенням $5 \%$ розчину тіопенталу натрію в розрахунку 40 мг/кг маси тіла та $1 \%$ розчину пропофолу з розрахунку 5 мг/кг маси тіла. Під час виконання хірургічних втручань, тварин фіксували до операційного столу, проводилась обробка місця втручання 0,05\% розчином хлоргексидину. Наносили різану повздовжню рану розміром $1,5-$ 2,0 см в довжину та 0,3-0,5 см в глибину за допомогою леза скальпеля № 15.

На 3,7 , та 14 добу тварин виводили з експерименту шляхом внутрішньочеревинного введення надлишку $5 \%$ розчину тіопенталу натрію та висікали зразки тканин для гістологічного дослідження. Відібрані зразки тканин фіксували в $10 \%$ розчині нейтрального формаліну протягом
24 годин, зневоднювали в етиловому спирті зростаючих концентрацій (від 70 до $100^{\circ} \mathrm{C}$ ), просвітлювали в ксилолі по 30 хв, витримували 2 години при температурі $37^{\circ} \mathrm{C}$ в суміші ксилолу та паpaфiну (1:1), та двічі в парафіні по 30 хв при $56^{\circ} \mathrm{C}$, ущільнювали у парафіні, виготовляли гістологічні зрізи товщиною 5 мкм, які забарвлювали гематоксиліном та еозином, пікрофуксином за ван Гізоном.

Проводилося фотодокументування гістологічних препаратів за допомогою цифрової камери світлооптичного мікроскопу Leica ICC50 HD i морфометрична обробка за допомогою відеоаналізатору і комп'ютерної програми "Paradise", poзробленою наукова-виробничою компанією «Сва».

Результати досліджень та ӥх обговорення. Макроскопічно на 3 добу після з'єднання країв рани шовним матеріалом на основі шовку спостерігалась гіперемія, перифокальна інфільтрація та набряк навколо швів. При огляді, кровоточивість 3 країв рани. На поверхні швів та у рановому каналі спостерігались залишки їжі. Краї рани роз'єднані, відстань 0,2-0,3 мм (табл. 1).

Таблиця 1

Місцеві (макроскопічні) ознаки загоєння ран СОПР, після застосування шовного матеріалу та n-бутил-2-ціаноакрилатної клейової композиції

\begin{tabular}{|c|c|c|c|c|c|c|c|c|c|c|c|c|c|c|}
\hline \multirow{3}{*}{ 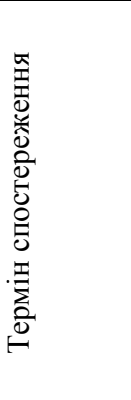 } & \multicolumn{7}{|c|}{$\begin{array}{c}\text { Шовний матеріал } \\
\text { Контрольна група } \\
\text { (12 тварин) }\end{array}$} & \multicolumn{7}{|c|}{$\begin{array}{c}\text { Клейова композиція } \\
\text { Основна група } \\
\text { (12 тварин) } \\
\end{array}$} \\
\hline & \multicolumn{7}{|c|}{ Критерії оцінки } & \multicolumn{7}{|c|}{ Критерії оцінки } \\
\hline & 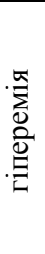 & 萨 & 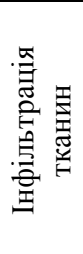 & 胥 & 疍 & 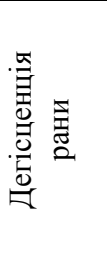 & 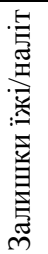 & 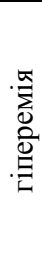 & 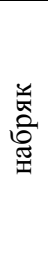 & 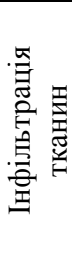 & 氦 & 竎 & 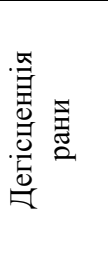 & 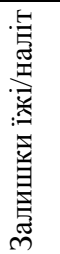 \\
\hline 3 доба & + & + & + & + & + & $\begin{array}{c}0,2- \\
0,3 \mathrm{MM}\end{array}$ & + & + & + & + & + & - & $\begin{array}{c}0,2- \\
0,3 \mathrm{MM}\end{array}$ & + \\
\hline 7 доба & + & + & + & - & - & - & + & - & - & - & - & - & - & - \\
\hline 14 доба & + & + & + & - & - & - & + & - & - & - & - & - & - & - \\
\hline
\end{tabular}

На 3 добу при гістологічному дослідженні препаратів СОПР, на поверхні рани грануляційна тканина була відсутня, рана вкрита масами детриту, краї рани частково утримувались згортком крові (рис. 1). Навколишні тканини мали ознаки вираженої нейтрофільно-лімфоцитарної інфільтрації, в якій переважали нейтрофільні гранулоцити. Макрофаги не численні, активовані, у них збільшений розмір цитоплазми, вона вакуолізована, просвітлена. Ознаки відновлення епітеліальної пластинки відсутні. Тканина навколо рани була васкуляризована, мала розширені, повнокровні кровоносні судини з ознаками стазу, переважно в капілярах та венулах на глибину
$(850,5 \pm 91,16)$ мкм. Нитки були помітні як на поверхні рани, так в глибині власної пластинки слизової оболонки. Власна пластинка навколо рани була набрякла, інфільтрована нейтрофільними гранулоцитами та лімфоцитами. Новоутворення колагенових волокон не відзначалось.

Макроскопічно на 7 добу після з'єднання країв рани шовним матеріалом, спостерігалась «неспроможність» швів та інвагінація країв рани в напрямку до середини ранового каналу. Перифокальна запальна реакція навколо швів була збережена, виражена помірно.

В зоні швів утворився значний об'єм грануляційної тканини, товщина його становила 
$(316,73 \pm 32,06)$ мкм. Новоутворена тканина була рясно васкуляризована та інфільтрована переважно нейтрофільними гранулоцитами та дещо в меншій кількості лімфоцитами (рис. 2). На відміну від 3 доби спостереження, кількість нейтрофільних гранулоцитів дещо зменшувалась, а кількість лімфоцитів збільшувалась. Макрофагів було небагато, вони утворювали невеликі скупчення по 3-4 клітини в зоні розташування філаментів шовкових ниток. Епітеліальна пластинка не відновлювалась, поверхня рани була оголена, вкрита масами детриту. Навколо мультифіламентних ниток, розташованих у власній пластинці

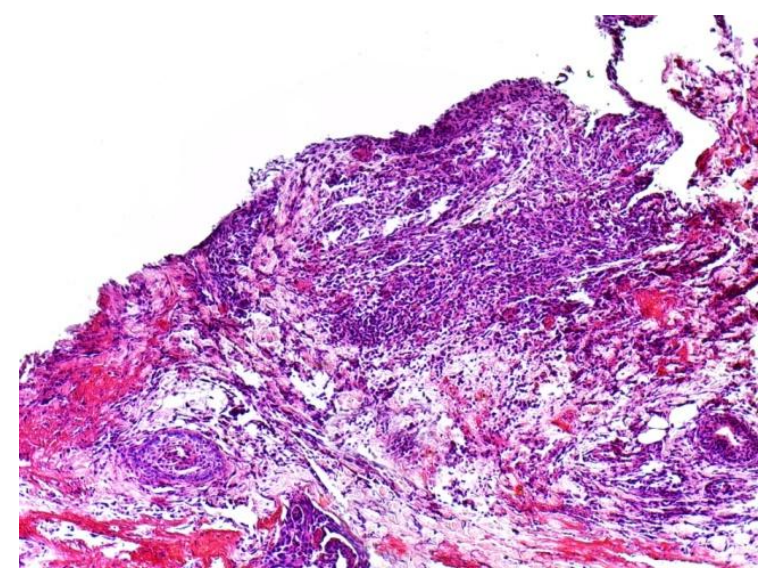

Рис. 1. СОПР кроля через 3 доби після накладання швів. Забарвлення гематоксиліном та еозином. Збільшення 100 слизової оболонки почали сформуватись сполучнотканинні капсули, що складались 3-5 рядів фібробластів і пучків колагенових волокон. Від капсули вглибину між філаментами ниток почали проростати тонкі прошарки 3 фібробластів. На деяких ділянках в товщі новоутвореної тканини відзначались невеликі гранульоми, що містили макрофаги та 2-3 гігантські клітини стороннього тіла (ГКСТ) що відзначались лише в складі гранульом. Порушення мікроциркуляції з повнокрів'ям та стазами в дрібних кровоносних судинах відзначалось до $(677,13 \pm 59,45)$ мкм в глибину (табл. 2).

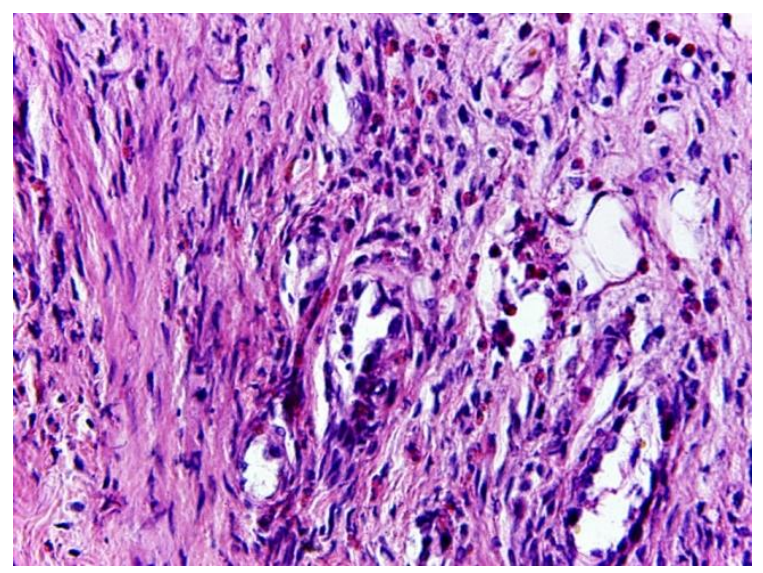

Рис. 2. СОПР кроля через 7 діб після накладання швів. Забарвлення гематоксиліном та еозином. Збільшення 400 .

Таблиця 2

Мікроскопічні ознаки загосння рани

СОПР після накладання швів на основі шовку

\begin{tabular}{|c|c|c|c|c|c|}
\hline Доба & $\begin{array}{c}\text { Глибина стазу } \\
\text { та порушення } \\
\text { мікроциркуляції } \\
\text { (мкм) }\end{array}$ & $\begin{array}{c}\text { Ознаки форму- } \\
\text { вання грануля- } \\
\text { ційної тканини } \\
\text { (мкм) }\end{array}$ & $\begin{array}{c}\text { Наявність } \\
\text { новоутворених } \\
\text { колагенових } \\
\text { волокон }\end{array}$ & $\begin{array}{c}\text { Наявність } \\
\text { стороннього } \\
\text { тіла у рані }\end{array}$ & $\begin{array}{c}\text { Епітеліальна } \\
\text { пластинка } \\
\text { (відновлення мкм) }\end{array}$ \\
\hline 3 & $850,5 \pm 91,16$ мкм & - & - & + & Відсутня \\
\hline 7 & $677,13 \pm 59,45$ мкм & $316,73 \pm 32,06$ мкм & + & + & Відсутня \\
\hline 14 & $636 \pm 61,04$ мкм & $688 \pm 71,15$ мкм & + & + & $\begin{array}{c}\text { Частково відновлена } \\
39,46 \pm 4,07 \text { мкм }\end{array}$ \\
\hline
\end{tabular}

Макроскопічно на 14 добу зберігалась перифокальна запальна реакція навколо швів. Спостерігалось лінійне сполучнотканинне утворення на місці втручання, з елементами деформації та нерівною поверхнею, що підвищувалось над рівнем інтактних ділянок слизової оболонки.

На 14 добу в зоні шва зберігалось виражене запалення. Зберігалась переважно нейтрофільна інфільтрація новоутвореної грануляційної тканини та навколишніх тканин, особливо в зоні розташування швів, 3 меншою кількістю лімфоцитів, проте відносно терміну спостереження на 7 добу, кількість цих клітин зростала. Кількість макрофагів також збільшувалась відносно попе- реднього терміну, гігантські клітини стороннього тіла дрібні, поодинокі (0-4 в полі зору), були помітні в складі гранульом, розташованих в зоні рубця. Епітеліальна пластинка не відновлювалась, на деяких ділянках спостерігалось іiї крайове потовщення. Новоутворена тканина ущільнювалась, потовщені колагенові волокна в ній розташовувалась більш компактно, хаотично (рис. 3). Порушення мікроциркуляції зберігалось до $(688 \pm 71,15)$ мкм в глибину.

Макроскопічно на 3 добу спостерігалось розходження країв рани на 0,2-0,3 мм. Краї рани дещо інфільтровані, без суттєвих ознак запалення. Поверхня рани вкрита фібриновим нальотом, 
що свідчить про початок відновних процесів у рані. Подекуди, на поверхні рани залишки їжі (табл. 1).

При гістологічному дослідженні СОПР кроля на 3 добу було встановлено: в зоні розташування клейових мас спостерігались помірно виражені ознаки запалення, клейові маси були оточені тонким прошарком новоутвореної тканини, який складався з 2-3 рядів фібробластів і тонких пучків колагенових волокон (товщина $16,05 \pm 0,92)$ мкм (табл.3), розташованими у власній пластинці слизової оболонки (рис. 4). Мали місце початкові ознаки регенерації, на відміну від терміну спостереження на 3 добу в контрольній групі. Навколишня тканина була помірно інфільтрована переважно лімфоцитами та нейтрофільними гранулоцитами, поодинокими макро-

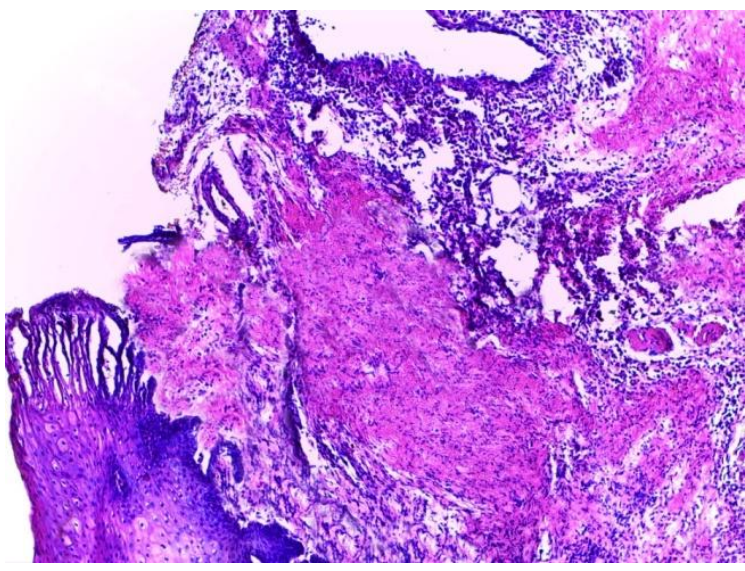

Рис. 3. СОПР кроля через 14 діб після накладання швів. Забарвлення гематоксиліном и еозином. Збільшення 100. фагами та гігантськими клітинами стороннього тіла (0-2 в полі зору). В поверхневому шарі власної пластинки навколо рани інфільтрація була переважно лімфоцитарна, на відміну в контрольній групі на 3 добу спостереження. Епітеліальна пластинка не відновлювалась. Кровоносні судини у власній пластинці та в оточуючій тканині були повнокровні розширені, прояви стазу спостерігались лише навколо зони розміщення клейових мас, порушення мікроциркуляції відзначалось на глибину $(705,8 \pm 75,2)$ мкм, різниця даного показника між двома групами на 3 добу склала $144,7 \pm 15,96$ мкм, на користь основної групи. Колагенові волокна, які входили до складу капсули, що починала формуватись навколо фрагментів клейових мас, були тонкі, більш поверхнево розташовані - пікринофільні, незрілі.

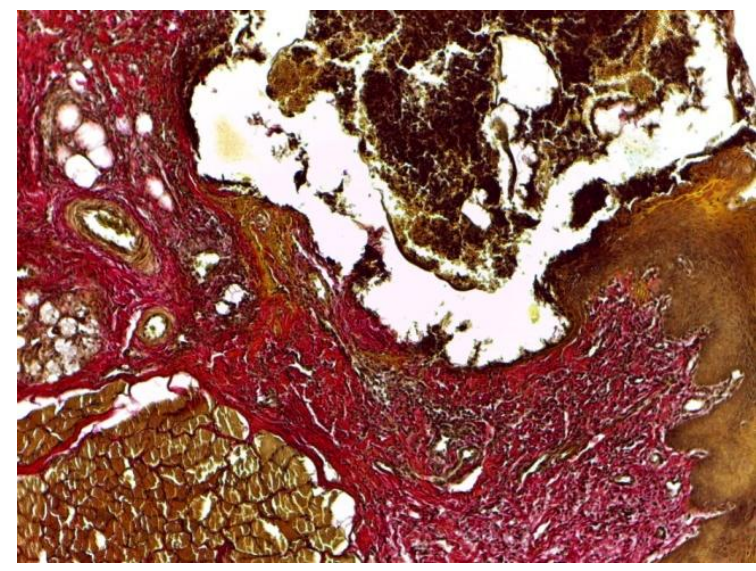

Рис. 4. СОПР кроля через 3 доби після з'єднання за допомогою n-бутил-2-ціаноакрилатної клейової композиції. Забарвлення пікрофуксином за ван Гізоном. Збільшення 100.

Таблиця 3

Мікроскопічні ознаки загосння рани СОПР після застосування n-бутил-2-ціаноакрилатної клейової композиції

\begin{tabular}{|c|c|c|c|c|c|}
\hline Доба & $\begin{array}{c}\text { Глибина стазу та } \\
\text { порушення мікро- } \\
\text { циркуляції } \\
\text { (мкм) }\end{array}$ & $\begin{array}{c}\text { Ознаки формування } \\
\text { грануляційної тка- } \\
\text { нини } \\
\text { (мкм) }\end{array}$ & $\begin{array}{c}\text { Наявність ново- } \\
\text { утворених колаге- } \\
\text { нових волокон }\end{array}$ & $\begin{array}{c}\text { Наявність сторон- } \\
\text { нього тіла у рані }\end{array}$ & $\begin{array}{c}\text { Епітеліальна } \\
\text { пластинка } \\
\text { (відновлення мкм) }\end{array}$ \\
\hline 3 & $705,8 \pm 75,2$ мкм & $16,05 \pm 0,92$ мкм & + & + & - \\
\hline 7 & $311,13 \pm 29,66$ мкм & $66,14 \pm 4,49$ мкм & + & $\begin{array}{c}\text { Частково віднов- } \\
\text { лена } \\
44,17 \pm 4,61 \text { мкм }\end{array}$ \\
\hline 14 & $303,05 \pm 26,91$ мкм & $89,47 \pm 5,96$ мкм & + & - & Відновлена \\
$70,49 \pm, 6,01$ мкм
\end{tabular}

Макроскопічно на 7 добу спостерігається слабко виражене сполучнотканинне утворення, що не підвищується над рівнем інтактних ділянок слизової оболонки. Ознаки запалення виражені слабко, поверхня зони втручання, подекуди 3 залишками фібрину. Залишки їжі у ділянці втручання відсутні тоді як в контрольній групі, спостерігаються.
При гістологічному дослідженні препаратів СОПР кроля на 7 добу в зоні обробки утворився прошарок грануляційної тканини 3 незрілими (пікринофільними) та зрілими (фуксинофільними) колагеновими волокнами, товщина прошарку становила $(66,14 \pm 4,49)$ мкм (табл. 3$)$, різниця даного показника між двома групами на 7 добу, склала 220,16 21,93 мкм, що свідчить про приш- 
видшення перебігу репаративного процесу в основній групі. На відміну від контрольної групи, інфільтрація зони рубця та навколишніх тканин, була переважно лімфоцитарна, нейтрофільні гранулоцити не численні, проте в зоні рубця тканина містила дрібні вогнища нейтрофільної інфільтрації, а також відзначались активовані макрофаги та поодинокі дрібні гігантські клітини сторонніх тіл. Ознаки запалення були помірно виражені. Фрагментів клейових мас в тканинах не спостерігалось (рис. 5). Епітеліальна пластинка, на відміну від контрольної групи, частково відновлювалась, ii товщина становила $(44,17 \pm 4,61)$ мкм (табл. 2,3$)$. Власна пластинка в

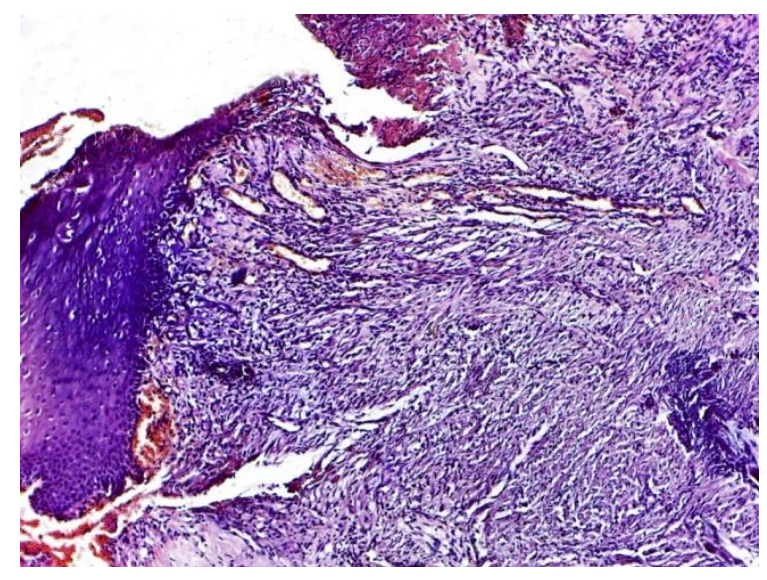

Рис. 5. СОПР кроля через 7 діб після з'єднання за допомогою n-бутил-2-ціаноакрилатної клейової композиції. Забарвлення гематоксиліном та еозином. Збільшення 100.

На 14 добу при гістологічному дослідженні препаратів СОПР кроля в зоні обробки епітеліальна пластинка була переважно відновлена, потоншена (рис. 6), тоді як в контрольній групі відновлена частково. На інтактних ділянках їі товщина становила $(179,71 \pm 18,26)$ мкм, на поверхні рубця $(70,49 \pm, 6,01)$ мкм, різниця даних показників склала $31,03 \pm 1,94$ мкм, що свідчить про більшу площу відновлення в основній групі. Власна пластинка на одній $з$ ділянок мала ознаки набряку, зона рубця була незначно інфільтрована лімфоцитами (рис. 6), дещо зменшувалась кількість нейтрофільних гранулоцитів, на відміну від контрольної групи, де показники лімфоцитарної інфільтрації були більш вираженими, що можна пояснити наявністю «стороннього тіла» у рані. Кровоносні судини повнокровні не мали ознак стазу. Колагенові волокна в зоні втручання були зрілі, більш компактно розташовані, ніж на інтактних ділянках, товщина прошарку грануляційної тканини становила $(89,47 \pm 5,96)$ мкм. Макрофаги нечисленні, дрібні гігантські клітини відзначались в глибині рубця лише на деяких ділянках. Порушення тонусу судин гемомікроциркуляторного русла відзначалось на глибину зоні втручання ущільнювалась через більш компактне розташування пучків колагенових волокон. Кровоносні судини, особливо капіляри та венули біли розширені та повнокровні, прояви стазу були відсутні. Порушення мікроциркуляції відзначалось на глибину $(311,13 \pm 29,66)$ мкм, різниця даних показників склала між двома групами склала $(366 \pm 29,79)$ мкм менше ніж в контродьній групі, на користь основної групи спостереження.

Макроскопічно на 14 добу на місці розрізу спостерігалось рівномірне сполучнотканинне утворення, яке місцями візуально не відрізнялось від інтактних ділянок СОПР.

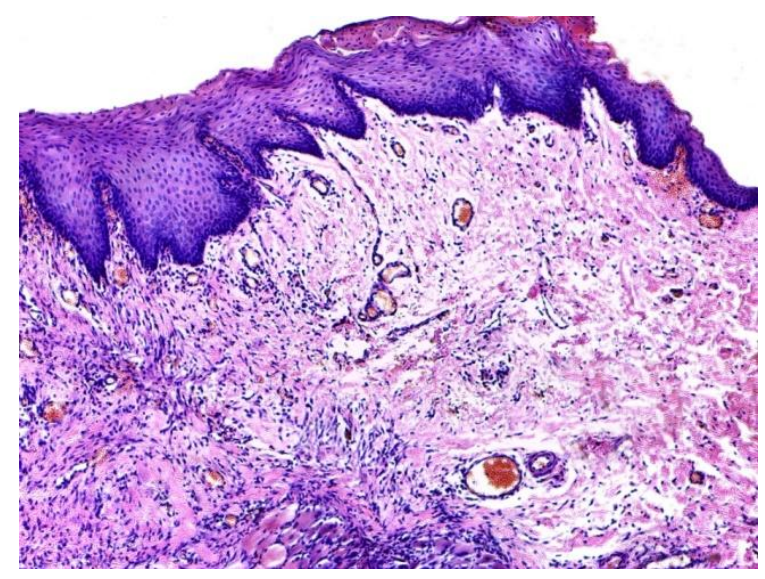

Рис. 6. СОПР кроля через 14 діб після з'єднання за допомогою n-бутил-2-ціаноакрилатної клейової композиції. Забарвлення гематоксиліном та еозином. Збільшення 100.

$(303,05 \pm 26,91)$ мкм, різниця даних показників склала $324,87 \pm 31,38$, що удвічі менше ніж в контрольній групі на 14 добу.

Висновки. 1. Виявлено різницю в регенерації слизової оболонки порожнини рота після з'єднання країв рани вузлуватими швами на основі шовку та n-бутил-2-ціаноакрилатною клейовою композицією в експерименті.

1. Застосування клейової композиції сприяло швидшому відновленню тканин в зоні хірургічного втручання, про що свідчать ознаки регенерації, які спостерігались 33 доби, а саме, поява молодих колагенових волокон та тонкого прошарку молодої грануляційної тканини, товщиною $16,05 \pm 0,92$ мкм.

2. Найбільш оптимальне загоєння рани в основній групі відбувалося на 7 добу після хірургічного втручання і проявлялось прискоренням формування ніжного нормотрофічного сполучнотканинного рубця, про що свідчить швидша зміна клітин лімфоцитарно-макрофагального ряду та часткове відновлення епітеліальної пласти-

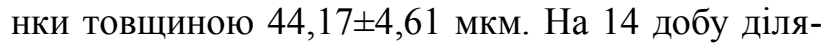
нка втручання не відрізнялась від навколишніх інтактних тканин. 
3. Перевагою використання клейової композиції в порівнянні із шовним матеріалом, починаючи 37 доби, є відсутність в післяопераційній рані «стороннього тіла», як наслідок, зменшення інтенсивності гігантоклітинних реакцій, прискорення регенеративних процесів у рані.

\section{Список літератури}

1. Аветіков Д. С. Гістотопографічна характеристика загоєння післяопераційних ран при застосуванні клейової композиції «Сульфакрилат» в порівнянні 3 традиційним ушиванням / Аветіков Д. С, Талаш Р. В, Старченко I. I // Актуальні проблеми сучасної медицини: Вісник Української медичної стоматологічної академії. - 2015. - Т. 15, № 3(51). - C. $149-153$.

2. Аветіков Д. С. Морфологічна характеристика ранніх етапів післяопераційного раневого процесу шкіри в залежності від способу фіксації країв рани / Аветіков Д. С., Лоза X. О., Старченко I.I // Актуальні проблеми сучасної медицини: Вісник Української медичної стоматологічної академії. - 2015. - Т. 15, № 1(49). - С. 149-152.

3. Gazivoda D. A clinical study on the influence of suturing material on oral wound healing / Gazivoda D., Pelemiš D., Vujašković G // Vojnosanit Pregl. - 2015. - №72(9). - P. 765-769.

4. Oladega A. A. Cyanoacrylate tissue adhesive or silk suture for closure of surgical wound following removal of an impacted mandibular third molar: A randomized controlled study / A. A. Oladega, O. James, W. L. Adeyemo // Journal of Cranio-Maxillo-Facial Surgery. - 2019. - V. 47, №.1. - P. 93 98.

5. Comparing intra-oral wound healing after alveoloplasty using silk sutures and n-butyl-2-cyanoacrylate / P Suthar [et al.] // J. Korean Assoc Oral. Maxillofac Surg. - 2020. - № 46. - P. 28-35.

6. Pippi R. Post-Surgical Clinical Monitoring of Soft Tissue Wound Healing in Periodontal and Implant Surgery / R. Pippi // International Journal of Medical Sciences. - 2017. №14(8). - P. 721-728.

7. Wound healing problems in the mouth / C. Politis [et al.] // Frontiers in Physiology. - 2016. - № 7. - P. 507.

8. Tissue reactions to various suture materials used in oral surgical interventions / Javed F [et al.] // ISRN Dent. 2012. -762095 .

9. Cyanoacrylate for intraoral wound closure: a possibility? / Sagar P [et al.] // International Journal of Biomaterials. 2015. - V. 2015. - P. 6

10. Лопухин Ю. М. Экспериментальная хирургия / Лопухин Ю. М - Монография. - М.: Медицина. - 1971. $346 \mathrm{c}$.

11. Каплун Д. В. Особливості морфологічної будови слизових клаптів порожнини рота в стані спокою і при їх розтягуванні / Д. В. Каплун, Д. С. Аветіков // Актуальні проблеми сучасної медицини: Вісник Української медичної стоматологічної академії. - 2019. - Т. 19, №2(66). - С. 113-8.

12. Шалимов А. А. Руководство по экспериментальной хирургии / А. А. Шалимов, А.П. Радзиховский, Л.В Кейсевич // - М.: Медицина. - 1989. - 270 с.

13. Денисов С. Д. Требования к научному експерименту с использованием животных / Денисов С. Д // Здравоохранение. - 2001. №4. - С. 40-42.

\section{REFERENCES}

1. Avetikov D. S., Talash R. V., Starchenko I. I Histotopographic characteristics of postoperative wound healing under applying adhesive composition «Sulphackrylate» compared with conventional suturing. Aktualni problemy suchasnoi medytsyny: Visnyk Ukrainskoi medychnoi stomatolohichnoi akademii. 2015; 3(51): 149-153.

2. Avetikov D. S., Loza Kh. O., Starchenko I. I. Morphological characteristics of early stages of postoperative skin wound depending on type of wound edges fixing. Aktualni problemy suchasnoi medytsyny: Visnyk Ukrainskoi medychnoi stomatolohichnoi akademii. 2015; 1(49): 149-152.

3. Gazivoda D., Pelemiš D., Vujašković G. A clinical study on the influence of suturing material on oral wound healing. Vojnosanit Pregl. 2015; 72(9): 765-769.

4. Oladega A. A., James O., Adeyemo W. L. Cyanoacrylate tissue adhesive or silk suture for closure of surgical wound following removal of an impacted mandibular third molar: A randomized controlled study. Journal of Cranio-MaxilloFacial Surgery. 2019; 47(1): 93-98.

5. Suthar P. et al. Comparing intra-oral wound healing after alveoloplasty using silk sutures and n-butyl-2cyanoacrylate. J. Korean Assoc Oral. Maxillofac Surg. 2020; 46: $28-35$

6. Pippi R. Post-Surgical Clinical Monitoring of Soft Tissue Wound Healing in Periodontal and Implant Surgery. International Journal of Medical Sciences. 2017; 14(8): 721-728.

7. Politis $\mathbf{C}$ et al. Wound healing problems in the mouth. Frontiers in Physiology. 2016; 7: 507.

8. Javed $\mathbf{F}$ et al. Tissue reactions to various suture materials used in oral surgical interventions. ISRN Dent. 2012; 762095 .

9. Sagar $\mathbf{P}$ et al. Cyanoacrylate for intraoral wound closure: a possibility? International Journal of Biomaterials. 2015 2015: 6 .

10. Lopuhin Ju M. Jeksperimental'naja hirurgija: Monografija [Experimental surgery: Monograph]. M: Medycyna; 1971: 346.

11. Kaplun D. V., Avetikov D. S. Peculiarities of the morphological structure of the oral mucosa flaps during rest and stretching. Aktualni problemy suchasnoi medytsyny: Visnyk Ukrainskoi medychnoi stomatolohichnoi akademii. 2019; 2(66): 113-8.

12. Shalimov A.A., Radzihovskij A.P., Kejsevich L.V. Rukovodstvo po jeksperimental'noj hirurgii. [Guide to experimental surgery]. M: Medycyna; 1989: 270.

13. Denisov S. D., Morozkina T. S. Requirements for a scientific experiment using animals. Zdravoohranenie. 2001; 4 40-42.

Надійшла 08.04.2020

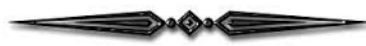

